UDC 633.2

(C) 2017

V. Kurhak, doctor of agricultural sciences

V. Voloshyn

National scientific center "Institute of Agriculture NAAS"

\title{
Efficiency of methods of recreation, fertilizing and utilization of meadow lands
}

The purpose. To determine influence of methods of recreation, fertilizing and utilization of meadow lands upon botanical compound, productivity and efficiency of growing grass stands on grey forest soils. Methods. Field, laboratory, mathematical-and-statistical. Results. It is fixed that the most efficient method of recreation of meadow lands is sowing of legume-grass mixtures with lucerne. That ensured the highest efficiency. Importation of N140 for legume-cereal grass stands decreased content of leguminous ingredients and was ineffective. For cereal grass stand and old lands such importation increased productivity in 1,8-2,0 times. Conclusions. Among varied grass stands in the alternative without fertilization the most productive one is lucerne-cereal grass stand, which at 2-hay cutting ensures the yield for 1 hectare of 8,10 tons of dry matter and 5,13 t/hectare of useful units. At 4-hay cutting it ensures 7,41 and 6, 35 t/hectare accordingly, that in 2,1-2,3 times more in comparison with seeded cereal grass stand. The level of accumulation of symbiotic nitrogen by lucerne made 142 - $154 \mathrm{~kg} / \mathrm{hectare}$.

Key words: efficiency, meadow lands, recreation, grass stand, botanical compound, fertilizing, utilization.

Introduction. In enhancing livestock fodder, herbal source of cheap food (hay, silage, green fodder, etc.) that are well balanced in protein, minerals and vitamins, as well as a factor in improving the environmental situation in agricultural landscapes, protecting soil from erosion, and water sources from pollution and siltation, plays an important role natural feeding grounds. Their area of Ukraine is about 8 million hectares. However, their fodder productivity and environmental opportunities have not used in full.

By researching of M.V. Kuksin [1], A.V. Bohovin [2], P.S. Makarenko [3], M.T. Yarmoliuk [4], V.H. Kurhak [5] and other scientists developed the principles of forming highly productive herbages of natural grasslands, the scientific basis for the creation, fertilizers and rational use of cultivated hayfields and pastures. However, current technological developments and improvement of their use of energy and resources is cost-based. It is not enough clarified methods of creating, usage and fertilizing of highly productive herbages on degraded natural grazing lands and in removed from the intensive cultivation soils of erosion-danger zone of agricultural landscapes, and especially the formation and use of fallow herbages in northern part of Right-bank Forest-steppe almost not studied, that was the reason for the research and lightening in this article.

Gained particular importance to the question of determining the best ways fast reproduction of grassland with necessity of improvement of ecological situation in agricultural landscapes by reducing ploughing of Ukraine areas and the removal of unproductive arable lands from intensive cultivation and transfer them under grasslands [6].

Analysis of recent researches and publications on the subject. To improve the efficiency of the livestock industry and to create a stable forage base and simultaneously improve the environmental situation by restoring the cultivation of perennial meadow grass on degraded grasslands and on arable lands erosion-prone areas agricultural lands. Meadow herbages provides the cheapest forage, and hence the cheapest livestock products. The increasing in the proportion of high quality grass forages from $55-60$ 
$\%$ to $85 \%$ in the diets when fed to cattle gives an opportunity to reduce cost of livestock production by more than $30 \%[7]$.

An important role in the formation of meadow cenosis, their productivity and forage quality plays the botanical composition, which occurs under the influence of meteorological and soil conditions, source composition, and age of herbage, usage of fertilizers, and so forth [8]. To obtain the highest possible yields, grassing should be legume-grass mixes. Such land is believed to be promising not only for high productivity - they improve the quality of forage and reduce the joint energy and costs. Seeded legumegrass herbages are the main source of feed protein [9]. Highly productive legume-grass herbages can be formed by reseeding perennial grasses in turf of old cereal cenosis, as well as after dropping the bean components to replace them for years of use.

The best results in productivity and efficiency among the means of reproduction grassland in the erosion-prone area of the cultivated lands, ensures sowing of legume-grass mixtures, as well as the way of reseeding the seeds of wild herbs typical of virgin areas, which accelerates the process of stabilization, conservation and reproduction of biodiversity of meadow grasses [10].

High efficiency of meadow grasses and grass-legume herbage to a considerable extent depend on usage which in turn leads to substantial positive and negative changes in herbage as a whole. Mowing leads to a rapid disruption of the normal rhythm of vegetation and the accumulation of spare substances in plants [11].

Effective use of perennial legumes as a cheap source of symbiotic nitrogen, in particular, methods of extending the productive longevity of legume-grass forages that include measures to overcome fatigue of soil or alternate placing legumes and grasses components in separate rows or strips, the rational combination of symbiotic and mineral nitrogen and other [10].

The analysis of literary sources shows that many scientists have paid attention this problem. However, a lot of questions about ways to developing, fertilizing and use of old-sowing and newly established herbages are researched insufficiently.

The aim of our researches was to determine the efficiency of recovery methods of recovery, fertilizers and use of grasslands.

Materials and methods of research. The research was conducted in NSC "Institute of agriculture NAAN". Experience laid down by overseeding of legumes and grasses in old cereal herbages in 2013 on land with gray forest soil, which are in the $0-10 \mathrm{~cm}$ layer contained $1.94-2.07 \%$ of humus, of alkaline hydrolyzed nitrogen - 67.9-74.9 to, mobile phosphorus - 15,5-21,0 and 7.5-10.4 mg/100 $\mathrm{g}$ of soil of exchange potassium with a $\mathrm{pH}$ of 5.4 to 5.5. Registered varieties of legumes and grasses were used. Investigation held at three fertilizer and two regimes of use. Phosphate and potassium fertilizers made in one term, nitrogen - in four equal portions during each mowing by using four mowing $\left(\mathrm{N}_{140}(35+35+35+35)\right.$ and two terms for two mowing $\left(\mathrm{N}_{140}(70+70)\right.$.

Replication of the experiment is fourfold. The size of cultivated plots $-10.5 \mathrm{~m}^{2}$, of accounting plots $3.15 \mathrm{~m}^{2}$. On the research plot in the fall of 2013 was made superficially lime $\left(\mathrm{CaCO}_{3}\right)$ at a dose of $5 \mathrm{t} / \mathrm{ha}$. The experiment scheme is given in table 1.

The experiments were performed according to standard techniques of research, which are used in forage production [12]. Was applied the following research methods: field, laboratory and mathematicalstatistical.

The research results indicate that on average over 2014-2016 for fallow in total herbages were not sowed cereals (59-81\%) and forbs (19-38\%). Moreover, on fallow-2 cereal grasses dominated on agrocenosis and on the forbs less when in fallow-1. Application of nitrogen fertilizers by $10 \%$ increased the number of grains. In nitrogen deficient backgrounds in the formation of over wetting herbages took wild species of legumes at list $5 \%$.

On grass herbage dominant position with a share of $55-66 \%$ were seeded grasses (Festuca pratensis and Bromus inermis), which were incorporated into the grass mixtures. The proportion of non-sowed cereals amounted to $24-27 \%$. 
In legume-grass mixtures as in cereals, were the largest proportion cereals which quantity was in the range of 47 to $71 \%$. Number of bean components accounted for $22-49 \%$ with the largest share of Lotus ukrainicus and alfalfa-grass mixtures. Nitrogen fertilization led to a decrease in the proportion of legumes in $9-21 \%$.

The total number of species of meadow plants that were present in mixtures of different variants accounted for 46 species of 15 families, and among wild components -41 species from 15 families. Of these, 13 species of family Gramineae (Bromus inermis, Dactylis glomerata, Festuca orientalis, Festuca rubra, Festuca valesiaca, Calamagrostis epigeios, Apera spica-venti, Poa angustifolia, Poa pratensis, Elymus repens, Agrostis capillaris, Setaria glauca, Echinochloa crus-galli) 24 species belonging to the group motley grasses, 4 species belonging to legumes (Vicia cracca, Trifolium repens, Trifolium hybridum, Lotus ukrainicus). Among the motley grasses the most species (11) were from the family Asteraceae (Achillea millefolium, Taraxacum officinale, Lactuca serriola, Sonchus arvensis, Artemisia absinthium, Artemisia vulgaris, Matricaria inodora, Senecio vulgaris, Senecio jacobaea, Erigeron canadensis and Phalacroloma annuum).

Non-sowed species took part in the formation of the meadow herbages represented by the following families: Asteraceae, Convolvulaceae, Leguminósae, Caryophyllaceae, Poligonaceae, Gramineae, Chenopodioideae, Malvaceae, Euphorbiaceae, Solanaceae, Plantaginaceae, Rosaceae, Equisetaceae, Brassicaceae and Violaceae.

Among all non-sowed 25 species belonged to the perennials and 16 species were biennial. It should be noted that the use of fallow lands amount of non-sowed annual crops gradually decreased and number of perennials species, on the contrary, increased.

Analysis of the data yield has shown that the most influential factors with the yield from 1 ha of dry weight were fertilizers factors and crop with the equity share on average over the three years, respectively, 43 and $39 \%$ (table. 1). In third place was the regime of use (9\%). Among the different types of mixtures average was for the 2014-2016. In the variant without fertilizers was the most productive alfalfa-grass herbage. On average over 3 years for use two mowing he provided to obtaining of $8,10 \mathrm{t} / \mathrm{ha}$ of dry weight and $5.13 \mathrm{t} / \mathrm{ha}$ of fodder units, and the four mowing - respectively 7.41 and $6.35 \mathrm{t} / \mathrm{ha}, 1,2$ 1,4 times compared with other legume-grass mixtures in 2.1-2.3 - compared with sowed cereal mixtures and 2.4-2.9 - times more than in fallow, which are formed by spontaneous overgrowth additional sowing and seeds of wild grasses, which harvested in the virgin area of the observable region. The level of accumulation of symbiotic nitrogen alfalfa seed ranged on $142-154 \mathrm{~kg} / \mathrm{ha}$.

Table 1. Productivity of different types of herbages depending on fertilizing systems and regimes of usage, middle in 2014-2016

\begin{tabular}{|c|c|c|c|c|c|c|c|}
\hline Herbage & Fertilizing & $\begin{array}{l}\text { Dry } \\
\text { weight, } \\
\text { t/ha }\end{array}$ & $\begin{array}{l}\text { Crude } \\
\text { protein, } \\
\text { t/ha }\end{array}$ & $\begin{array}{l}\text { Feed unit, } \\
\text { t/ha }\end{array}$ & $\begin{array}{l}\text { Nsymb., } \\
\text { kg/ha }\end{array}$ & $\begin{array}{l}\text { Repay } 1 \mathrm{~kg} \\
\text { of nitrogen. }\end{array}$ & $\begin{array}{l}\text { Legumes } \\
\text { content, \% }\end{array}$ \\
\hline \multicolumn{8}{|l|}{ Two mowing usage } \\
\hline \multirow{3}{*}{$\begin{array}{l}\text { Fellow land-1 } \\
\text { (spontaneous } \\
\text { overgrowing) }\end{array}$} & No fertilizing & 2.75 & 0.36 & 1.70 & - & - & 3 \\
\hline & $\mathrm{N}_{140}$ & 5.47 & 0.82 & 3.43 & - & 19 & - \\
\hline & $\mathrm{N}_{140} \mathrm{P}_{60} \mathrm{~K}_{120}$ & 5.78 & 0.89 & 3.66 & - & - & - \\
\hline \multirow{3}{*}{$\begin{array}{l}\text { Fellow land-2 } \\
\text { (undersow of wild } \\
\text { grasses) }\end{array}$} & No fertilizing & 2.91 & 0.38 & 1.72 & - & - & - \\
\hline & $\mathrm{N}_{140}$ & 6.24 & 0.96 & 3.71 & - & 24 & 5 \\
\hline & $\mathrm{N}_{140} \mathrm{P}_{60} \mathrm{~K}_{120}$ & 6.37 & 1.01 & 3.79 & - & - & - \\
\hline \multirow{3}{*}{$\begin{array}{l}\text { Sowing-cereal } \\
\text { herbage }\end{array}$} & No fertilizing & 3.59 & 0.41 & 1.87 & - & - & - \\
\hline & $\mathrm{N}_{140}$ & 7.13 & 1.01 & 3.65 & - & 26 & - \\
\hline & $\mathrm{N}_{140} \mathrm{P}_{60} \mathrm{~K}_{120}$ & 7.68 & 1.13 & 3.95 & - & - & - \\
\hline \multirow[t]{2}{*}{ Alfalfa-cereal herbage } & No fertilizing & 8.10 & 1.30 & 5.13 & 142 & - & 46 \\
\hline & $\mathrm{N}_{140}$ & 8.93 & 1.53 & 5.37 & 83 & 6 & 25 \\
\hline
\end{tabular}




\begin{tabular}{|c|c|c|c|c|c|c|c|}
\hline & $\mathrm{N}_{140} \mathrm{P}_{60} \mathrm{~K}_{120}$ & 9.40 & 1.63 & 5.75 & 81 & - & 27 \\
\hline \multirow{3}{*}{$\begin{array}{l}\text { Meadow clover-cereal } \\
\text { herbage }\end{array}$} & No fertilizing & 6.15 & 0.89 & 3.79 & 76 & - & 35 \\
\hline & $\mathrm{N}_{140}$ & 8.03 & 1.32 & 4.81 & 49 & 14 & 22 \\
\hline & $\mathrm{N}_{140} \mathrm{P}_{60} \mathrm{~K}_{120}$ & 8.45 & 1.41 & 5.15 & 45 & - & 22 \\
\hline \multirow{3}{*}{$\begin{array}{l}\text { White clover-cereal } \\
\text { herbage }\end{array}$} & No fertilizing & 5.64 & 0.86 & 3.70 & 73 & - & 31 \\
\hline & $\mathrm{N}_{140}$ & 7.52 & 1.23 & 4.72 & 35 & 14 & 23 \\
\hline & $\mathrm{N}_{140} \mathrm{P}_{60} \mathrm{~K}_{120}$ & 7.75 & 1.29 & 4.95 & 26 & - & 22 \\
\hline \multirow{3}{*}{ Bird's-foot herbage } & No fertilizing & 5.89 & 0.97 & 3.91 & 90 & - & 49 \\
\hline & $\mathrm{N}_{140}$ & 7.87 & 1.31 & 5.02 & 48 & 14 & 36 \\
\hline & $\mathrm{N}_{140} \mathrm{P}_{60} \mathrm{~K}_{120}$ & 8.11 & 1.38 & 5.20 & 40 & - & 35 \\
\hline \multicolumn{8}{|l|}{ Four mowing usage } \\
\hline \multirow{3}{*}{$\begin{array}{l}\text { Fellow land-1 } \\
\text { (spontaneous } \\
\text { overgrowing) }\end{array}$} & No fertilizing & 2.71 & 0.47 & 2.06 & - & - & - \\
\hline & $\mathrm{N}_{140}$ & 5.40 & 1.00 & 4.13 & - & 20 & - \\
\hline & $\mathrm{N}_{140} \mathrm{P}_{60} \mathrm{~K}_{120}$ & 6.09 & 1.14 & 4.72 & - & - & - \\
\hline \multirow{3}{*}{$\begin{array}{l}\text { Fellow land-2 } \\
\text { (undersow of wild } \\
\text { grasses) }\end{array}$} & No fertilizing & 3.04 & 0.51 & 2.20 & - & - & - \\
\hline & $\mathrm{N}_{140}$ & 6.20 & 1.15 & 4.49 & - & 23 & - \\
\hline & $\mathrm{N}_{140} \mathrm{P}_{60} \mathrm{~K}_{120}$ & 6.54 & 1.23 & 4.82 & - & - & - \\
\hline \multirow{3}{*}{$\begin{array}{l}\text { Sowing-cereal } \\
\text { herbage }\end{array}$} & No fertilizing & 3.50 & 0.52 & 2.33 & - & - & - \\
\hline & $\mathrm{N}_{140}$ & 6.93 & 1.26 & 4.52 & - & 25 & - \\
\hline & $\mathrm{N}_{140} \mathrm{P}_{60} \mathrm{~K}_{120}$ & 7.34 & 1.35 & 4.79 & - & - & - \\
\hline \multirow{3}{*}{ Alfalfa-cereal herbage } & No fertilizing & 7.41 & 1.49 & 6.35 & 154 & - & 41 \\
\hline & $\mathrm{N}_{140}$ & 8.62 & 1.78 & 7.33 & 83 & 9 & 24 \\
\hline & $\mathrm{N}_{140} \mathrm{P}_{60} \mathrm{~K}_{120}$ & 9.05 & 1.91 & 7.74 & 90 & - & 23 \\
\hline \multirow{3}{*}{$\begin{array}{l}\text { Meadow clover-cereal } \\
\text { herbage }\end{array}$} & No fertilizing & 5.83 & 1.09 & 4.86 & 91 & - & 33 \\
\hline & $\mathrm{N}_{140}$ & 8.16 & 1.60 & 6.68 & 55 & 17 & 25 \\
\hline & $\mathrm{N}_{140} \mathrm{P}_{60} \mathrm{~K}_{120}$ & 8.54 & 1.71 & 7.07 & 58 & - & 24 \\
\hline \multirow{3}{*}{$\begin{array}{l}\text { White clover-cereal } \\
\text { herbage }\end{array}$} & No fertilizing & 5.70 & 1.11 & 5.00 & 94 & - & 38 \\
\hline & $\mathrm{N}_{140}$ & 7.35 & 1.46 & 6.24 & 32 & 12 & 25 \\
\hline & $\mathrm{N}_{140} \mathrm{P}_{60} \mathrm{~K}_{120}$ & 7.61 & 1.51 & 6.43 & 27 & - & 26 \\
\hline \multirow{3}{*}{ Bird's-foot herbage } & No fertilizing & 5.97 & 1.23 & 5.27 & 114 & - & 48 \\
\hline & $\mathrm{N}_{140}$ & 7.51 & 1.55 & 6.41 & 47 & 11 & 33 \\
\hline & $\mathrm{N}_{140} \mathrm{P}_{60} \mathrm{~K}_{120}$ & 7.95 & 1.66 & 6.84 & 50 & - & 33 \\
\hline \multirow{3}{*}{$\mathrm{LSD}_{05}, \mathrm{t} / \mathrm{ha}$ on factors } & herbage & 0.22 & - & - & - & - & - \\
\hline & fertilizing & 0.18 & - & - & - & - & - \\
\hline & usage & 0.18 & - & - & - & - & - \\
\hline \multirow{3}{*}{ Parts of factors } & herbage & 39 & - & - & - & - & - \\
\hline & fertilizing & 43 & - & - & - & - & - \\
\hline & usage & 9 & - & - & - & - & - \\
\hline
\end{tabular}

The second highest level of productivity and symbiotic nitrogen accumulation was meadowclover/cereal herbage, while in the third year - bird's-foot trefoil/cereal, which unlike meadow clover, which almost fell out of the herbage, bird's-foot trefoil (Lotus ukrainicus) well preserved. In the nitrogen fertilizer best respond fallow and cereal herbages where also dominated by grasses. Introducing of $\mathrm{N}_{140}$ increased herbage productivity an average of 2.75-3.59 to 5.78-7.68 t/ha of dry weight (2.1 times), whereas in legume-grass mixtures $-5.64-8.10$ to $7.52-8.93$ t/ha of dry weight or only 1.1-1.3 times.

In contrast to nitrogen, phosphorus and potassium fertilizers in doses $\mathrm{P}_{60} \mathrm{~K}_{120}$ had significantly less impact on the performance of herbages. Collection from 1 ha of dry weight increased only by 0.13 to $0.69 \mathrm{t}$. 
Analysis of usage regimes showed that they had little impact on productivity. For the output from 1 ha of dry weight a slight advantage in most on the fertilized variants had two mowing mode of use, compared to four mowing.

Meanwhile, the release of 1 ha of fodder units and crude protein in variants with the introduction of nitrogen fertilizers was slightly higher productivity by use four mowing than two mowing.

\section{Conclusion}

Research has established that the formation of different types of meadow herbages (sown cereal and legume-grass and fallow lands) participated in all 46 species of 15 families, including 41 species from 15 families of wild flora.

Among the different types of herbage in the absence of fertilizer is the most productive seeded alfalfagrass herbage, which two mowing usage provides obtaining from $8.10 \mathrm{t} / \mathrm{ha}$ of dry mass and of $5.13 \mathrm{t} / \mathrm{ha}$ of fodder units, and for four mowing respectively of 7.41 and $6.35 \mathrm{t} / \mathrm{ha}$.

At best reaction on fertilizers have fellow land and cereal herbages with grasses domination, which at introduction of $\mathrm{N}_{140}$ with fragmented uniform input of nitrogen under mowing productivity increased from 2.75-3.59 to 5.78-7.68 t/ha of dry weight or 2,1 times while on legume-grass mixtures - from 5.64-8.10 to 7.52-8.93 $\mathrm{t} / \mathrm{ha}$ of dry weight or only 1.1-1.3 times.

\section{Bibliography}

1. Kuksin M.V. Stvorennia i ratsionalne vykorystannia kulturnykh pasovyshch / M.V. Kuksin. - K. : Urozhai, 1973. - $276 \mathrm{~s}$.

2. Bohovin A.V. Trav'ianysti bioheotsenozy, yikhnie polipshennia ta ratsionalne vykorystannia / A.V. Bohovin, I.T. Sliusar, M.K. Tsarenko. - K. : Ahrarna nauka, 2005. - $360 \mathrm{~s}$.

3. Makarenko P.S. Lukivnytstvo / P.S. Makarenko, H.I. Demydas, O.M. Koziar. - K. : Nora-print, 2002. $-394 \mathrm{~s}$.

4. Yarmoliuk M.T. Ahroekobiolohichni osnovy stvorennia ta vykorystannia luchnykh fitotsenoziv: monohr. / M.T. Yarmoliuk, H.M. Sedilo, H.S. Konyk ta in. - Lviv, 2013. - 304 s.

5. Kurhak V.H. Luchni ahrofitotsenozy / V.H. Kurhak. - K.: DIA, 2010. - 376 s.

6. Zurek G. Use of amenity grasses - status quo and innovations / G. Zurek // Grassland - a European Resource? / Pr. of $24^{\text {th }}$ Gen. Meeting of the Europ. Grassland Federation. - Lublin. - Poland. 2012. V. 17. - P. 436-444.

7. Klesnil A. Jeffektivnost' dlitel'nogo intensivnogo udobrenija estestvennyh travostoev / A. Klesnil, J. Velih, F. Turek // Nekotorye voprosy intensifikacii zemledelija SSSR i ChSSR. - M., 1977. - S. 10-19.

8. Voloshin V.N. Botanicheskij sostav i produktivnost' lugovyh travostoev na seryh lesnyh pochvah / V.N. Voloshin // Vestnik belorusskoj gosudarstvennoj sel'skohozjajstvennoj akademii. - 2017. - №1. - S. 62-66.

9. Luscher A. Sumbiotic nitrogen fixation of grass-clover leys under organic and conventional cropping / A. Luscher., E. Frossard., J. Mayer., P. Mader.,and A. Oberson // Grassland - a European Resource? I Pr. of $24^{\text {th }}$ Gen. Meeting of the Europ. Grassland Federation. - Lublin. - Poland. - 2012. V. 17. - P. 67-69.

10. Kurhak V.H. Ratsionalne vykorystannia pryrodnykh kormovykh uhid Ukrainy / V.H. Kurhak // Zb. naukovykh prats Instytutu zemlerobstva NAAN. - K., 2013. - Vyp. 3-4. - S. 93-102.

11. Rabotnov T.A. Biologicheskie i jekologicheskie osnovy racional'nogo ispol'zovanija i uluchshenija senokosov i pastbishh / T.A. Rabotnov // Prirodnye senokosy i pastbishha. - M. : Izd-vo s.h. literatury, zhurnalov j plakatov. - 1963. - S. 80-163.

12. Babych A.O. Metodyka provedennia doslidiv po kormovyrobnytstvu / A.O. Babych. - Vinnytsia, 1993. $-73 \mathrm{~s}$. 